\title{
Hubungan antara Pemeriksaan Antibodi Dengue IgG dengan Uji Fungsi Hati (SGOT dan SGPT) pada Pasien Demam Berdarah Dengue (DBD) di RSUD dr. M. Yunus bengkulu Bulan Desember 2015 - Januari 2016
}

\author{
Marlia Novelia $^{1}$, Mulyadi Mulyadi ${ }^{2}$, Enny Nugraheni $^{1}$ \\ 1. Fakultas Kedokteran dan IImu Kesehatan Universitas Bengkulu \\ 2. Rumah Sakit Umum Daerah M. Yunus Bengkulu
}

\begin{abstract}
ABSTRAK
Latar Belakang: Demam Berdarah Dengue merupakan suatu infeksi yang disebabkan oleh virus dengue dengan gejala klinis terjadinya demam mendadak 2-7 hari, tanda-tanda perdarahan, hepatomegali, syok apabila tidak ditegakkan secara cepat akan menyebabkan komplikasi dan kematian. Penelitian ini bertujuan untuk mengetahui hubungan pemeriksaan antibodi dengue IgG dengan uji fungsi hati SGOT dan SGPT pada pasien DBD.

Metode: Penelitian ini menggunakan studi analitik dengan pendekatan cross-sectional. Penelitian dilaksanakan pada bulan Desember 2015 sampai Januari 2016 di Laboratorium RSUD dr. M. YunuS. Pengambilan sampel dilakukan dengan menggunakan teknik consecutive sampling. Penilaian Pemeriksaan antibodi dengue $\operatorname{lgG}$ menggunakan dengue rapid test SD Dengue $\operatorname{lgG} / \operatorname{lgM}^{\circledR}$. Penilaian uji fungsi hati (SGOT dan SGPT) menggunakan uji kimia Autoanalyzer (architect plus $c 4000^{\circledR}$ ). Variabel bebas adalah antibodi dengue lgG, sedangkan variabel terikat adalah uji fungsi hati SGOT dan SGPT. Analisis data dilakukan dengan univariat dan bivariat dengan menggunakan uji statistik Koefisien Kontingensi.

Hasil Penelitian: Jumlah subjek penelitian sebanyak 32 orang, terdiri dari perempuan sebanyak 20 orang $(62.5 \%)$ lebih banyak daripada laki-laki sebanyak 12 orang $(37.5 \%)$ dengan usia paling muda 3 tahun dan usia paling tua 65 tahun. Hasil analisis bivariat menunjukkan bahwa nilai SGOT $p=0.149$ dan SGPT $p=0.108(p>0.05)$ tidak terdapat hubungan yang bermakna antara dua variabel yang diuji dan nilai korelasi Koefisien Kontingensi SGOT $r 0.247$ dan SGPT $r 0.273$ menunjukkan bahwa arah korelasi positif dengan kekuatan korelasi lemah.

Simpulan: Terdapat hubungan positif lemah tidak bermakna antara pemeriksaan antibodi dengue $\lg G$ dengan uji fungsi hati (SGOT dan SGPT) pada pasien demam berdarah dengue (DBD) di RSUD M. Yunus Bengkulu bulan Desember 2015 sampai Januari 2016.
\end{abstract}

Kata kunci: Antibodi dengue IgG, SGOT, SGPT, DBD

\section{The Relationship between Examination of IgG Antibodies Dengue and Examination of Liver Function Tests (SGOT and SGPT) in Patients with Dengue Hemorrhagic Fever (DHF) at General Hospital dr. M. Yunus Bengkulu during December 2015-January 2016}

\begin{abstract}
Background: DHF is infections caused by dengue virus with clinical symptoms are sudden fever for 2 - 7 days, bleeding, hepatomegaly, shock if it is not diagnosed quickly will cause death. This study aim is to determine the relationship between examination of dengue $\lg$ antibodies and examination of liver function tests (SGOT and SGPT) in patients with Dengue Hemorrhagic Fever (DHF). Methods:This study is an analytical study with cross sectional method. This study held on December 2015 until January 2016 at laboratory and room care of General Hospital dr. M. Yunus using sampling techniques consecutive sampling. Assessment Examination rapid diagnostic test brand SD Dengue $\operatorname{lgG} / \operatorname{lgM}^{\circledR}$. Assessment liver function tests (SGOT and SGPT) used chemical test Autoanalyzer (architect plus $c 4000^{\circledR}$ ). The dependent variable is dengue $\lg G$ antibodies, while the dependent variable is liver function tests (SGOT and SGPT). Data analysis was performed using univariate and bivariate analysis with contingency coefficient test.
\end{abstract}


Results: Amount subjects in this study were 32 people, consist of 20 women $(62.5 \%)$ more than men as many as 12 people (37.5\%) with the youngest age 3 years old and the oldest 65 years of age. Results of bivariate analysis showed that SGOT $p=0,149$ and SGPT $p=0,108(p>0.05)$ there is no significant relationship between the two variables teste dan the value ofthe correlation coefficient contingency SGOT $r 0,247$ and SGPT $r 0,273$ indicate that the direction is a positive correlation with the strength of the correlation weak.

Conclusion: There is an insignificant weak positive correlation relationship between examination of dengue IgG antibodies and examination of liver function tests (SGOT and SGPT) in patients with Dengue Hemorrhagic Fever (DHF) at General Hospital dr. M. Yunus Bengkulu during december 2015 until January 2016.

Keywords: Dengue IgG antibodies, SGOT, SGPT, DHF

\section{PENDAHULUAN}

Demam berdarah dengue merupakan suatu infeksi yang disebabkan oleh virus dengue yang diperantai oleh nyamuk yaitu Aedes aegypti dan Aedes albopictus(Soedarto, 2011) ${ }^{1}$. Dua spesies nyamuk tersebut termasuk spesies Flaviviridae, yaitu genus Flavivirus dengan Dengue-1, Den-2, Den-3, dan Den-4 serotype. ${ }^{2}$ Aedes aegypti sebagai vektor utama nyamuk domestik di daerah perkotaan, hidup di dalam dan sekitar rumah.

Aedes albopictus sebagai vektor sekunder hidup dan berkembang biak di kebun atau semak-semak di daerah perdesaan. ${ }^{3}$ Gejala Klinis pada pasien DBDterjadi peningkatan suhu tubuh $\geq 38^{\circ} \mathrm{C}$ selama 2-7 hari, perdarahan yang biasanya didahului dengan terlihatnya tanda khas berupa bintik merah (petekie),nyeri kepala, nyeri retroorbital, nyeri otot,dapat mengalami syok dan kematian. ${ }^{4}$

Demam berdarah dengue (DBD) masih merupakan salah satu masalah kesehatan masyarakat yang utama di Indonesia. ${ }^{5}$ Menurut Profil Kesehatan Indonesia tahun 2013 yang diterbitkan oleh Kementerian Kesehatan, angka kejadian DBD di Indonesia pada tahun 2012 jumlah penderita DBD dilaporkan sebanyak 90.245 kasus dengan jumlah kematian 816 orang, Incidence Rate (IR)/ Angka kesakitan 37,11 per 100.000 penduduk dan Case Fatality Rate (CFR) 0,90\%. Kejadian DBD di Bengkulu tahun 2012 menurut Profil Kesehatan Indonesia dilaporkan sebanyak 967 kasus dengan jumlah kematian 
7 orang (IR 53,60 per 100.000 penduduk dan CFR $0,72 \%){ }^{6}$

Penegakkan diagnosis klinis infeksi virus dengue di samping gejala klinis, pemeriksaan fisik, perlu juga ditunjang hasil pemeriksaan darah di laboratorium. Salah satunya dengan Pemeriksaan dengue rapid test SD Dengue $\operatorname{lgG} / \operatorname{lgM}{ }^{\circledR}$ digunakan untuk mendeteksi lgG/lgM dan menentukan demam yang diakibatkan virus dengue atau demam yang disebabkan oleh penyebab lain. ${ }^{5}$ Infeksi virus dengue dapat menyebabkan kerusakan sel hati, kerusakan pada sel hati akan meningkatkan jumlah enzim, peningkatan enzim tersebut dapat dilakukan pemeriksaan berupa Serum Glutamic-Oxaloacetic Transminase(SGOT) dan Serum Gtutamic Pyruvic Transminase (SGPT).SGOT dan SGPT walaupun bukan satu-satunya petanda fungsi hati, namun keberadaannya seringkali digunakan sebagai screening enzyme, merupakan parameter dasar untuk suatu diagnosis dan follow up terhadap gangguan fungsi hati. SGOT dapat ditemukandi hati juga di jantung, otot rangka, ginjal dan dalam jumlah yang banyak, sedangkan SGPT berasal dari hati. ${ }^{7,8}$

Berdasarkan latar belakang diatas serta belum adanya data yang lengkap penderita DBD di RSUD dr. M. Yunus maka perlu dilakukan penelitian tentang hubungan antara pemeriksaan antibodi dengue $\lg G$ dengan uji fungsi hati (SGOT dan SGPT) pada pasien demam berdarah dengue (DBD) di RSUD M. Yunus Bengkulu bulan Desember 2015 sampai Januari 2016.

\section{SUBJEK DAN METODE PENELITIAN}

Penelitian studi analitik dengan penedekatan cross sectionaldilakukan di Laboratorium dan ruang perawatan RSUD dr. M. Yunus Bengkulu pada bulan Desember 2015 sampai dengan Januari 2016. Populasi penelitian adalah pasien yang terdiagnosis demam berdarah dengue dengan besar sampel minimal 30 orang menggunakan rumus korelasi dan teknik pengambilan sampel menggunakan consecutive sampling. Teknik pengumpulan data merupakan pasien yang terdiagnosis DBD oleh dokter yang merawat dengan data primer yang didapatkan dari wawancara dan subjek penelitian yang melakukan pemeriksaan antibody dengue $\lg G$ menggunakan Standard Diagnostic (SD) Dengue $\lg G / \operatorname{lgM}^{\circledR}$ dan sensitifitas $94,6 \%$ dan spesifisitas 96,5\% kemudian dilakukan uji fungsi hati (SGOT dan SGPT) menggunakan uji kimia autoanalyzer (architect plus $\mathrm{c} 4000^{\circledR}$ ).Analisis data menggunakan analisis 
univariat dan bivariat dengan menggunakan uji statistik Koefisien Kontingensi yang ditampilkan dalam bentuk tabel.

\section{HASIL}

Sampel penelitian ini sebanyak 32 orang, terdiri dari perempuan 20 orang $(62.5 \%)$ dan laki-laki 12 (37.5\%), terdiri usia yang paling banyak pada umur 0-20 tahun sebanyak 15 orang (56.8\%). Klasifikasi derajat DBA dan jenis infeksi DBD diperlihatkan pada tabel $2 .{ }^{9}$
(12.5\%), derajat II sebanyak 27 orang (84.4\%) dan derajat III sebanyak 1 orang (3.1\%).

Hasil pemeriksaan antibodi yang didapatkan dalam penelitian ini terlihat pada tabel 2 terdiri dari $\lg$ G positif sebanyak 21 orang (65.5\%), dan $\lg$ negatif sebanyak 11 orang (34.4\%). Dari hasil tersebut didapatkan rerata hasil pengukuran SGOT adalah 85.31 $\pm 73.975 \mathrm{U} / \mathrm{L}$, dengan nilai terendah 18 $\mathrm{U} / \mathrm{L}$ dan nilai tertinggi $325 \mathrm{U} / \mathrm{L}$. Rerata hasil pengukuran SGPT adalah $65.06 \pm 67.452 \mathrm{U} / \mathrm{L}$,

Tabel 1. Distribusi frekuensi subjek penelitian berdasarkan jenis infeksi dengue dan derajat $\mathrm{DBD}$

\begin{tabular}{llcc}
\hline & Variabel & $\begin{array}{c}\text { Frekuensi } \\
\text { (Orang) }\end{array}$ & Persentase (\%) \\
\hline Infeksi Dengue & Primer & 9 & 28.1 \\
& Sekunder & 21 & 65.6 \\
Derajat DBD & DBD Derajat I & 4 & 12.5 \\
& DBD Derajat II & 27 & 84.4 \\
& DBD Derajat III & 1 & 3.1 \\
\hline
\end{tabular}

Pada tabel 1 digambarkan tentang infeksi dengue yang terjadi terdiri dari primer 9 orang (28.1\%), sekunder 21 (65.6\%) dan tidak terdeteksi primer atau sekunder sebanyak 2 orang (6.2\%). Derajat DBD diklasifikasikan berdasarkan diagnosis dokter yang merawat pasien didapatkan derajat I sebanyak 4 orang dengan nilai terendah $11 \mathrm{U} / \mathrm{L}$ dan nilai tertinggi $334 \mathrm{U} / \mathrm{L}$. 
Tabel 2 Distribusi frekuensi subjek penelitian berdasarkan antibodi dengue IgG dan Kadar uji fungsi hati

\begin{tabular}{lccc}
\hline \multicolumn{2}{c}{ Karakteristik } & $\begin{array}{c}\text { Rerata } \\
\text { (SD) }\end{array}$ & $\mathbf{n}(\%)$ \\
\hline $\begin{array}{llc}\text { Antibodi } \\
\text { dengue }\end{array}$ & $\operatorname{lgG}+$ & & 21 \\
lgG & IgG - & & $(65.5 \%)$ \\
& & & $(34.4) \%$ \\
Kadar uji & SGOT & $85.31 \pm 73.9$ & \\
& & $75 \mathrm{U} / \mathrm{L}$ & \\
Fungsi & SGPT & $65.06 \pm 67.4$ & \\
hati & & $52 \mathrm{U} / \mathrm{L}$ & \\
\hline
\end{tabular}

Hasil analisis korelasi kontingensi antara IgG dengan kadar SGOT dan SGPT didapatkan nilai signifikansi dari pemeriksaan SGOT p0.149 dengan nilai koefisien korelasi adalah 0.247 sedangkan pada SGPT p0.108 dengan nilai koefisien korelasi adalah 0.273. Hasil uji korelasi Koefisien Kontingensi yang digunakan menunjukkan bahwa hubungan positif yang lemah dan secara statistik tidak bermakna antara IgG dengan SGOT dan SGPT pada pasien DBD di RSUD dr. M. Yunus

\section{PEMBAHASAN}

Pada penelitian ini dari 32 sampel penelitian didapatkan perempuan lebih banyak menderita DBD dibandingkan laki laki. Hal ini dosebabkan bahwa perempuan lebih berisiko terhadap penyakit yang disebabkan virus dengue untuk mendapatkan manifestasi klinik yang lebih berat dibandingkan laki-laki. Hal ini berdasarkan dugaan bahwa dinding kapiler pada perempuan lebih cenderung dapat meningkatkan permeabilitas kapiler dibanding dengan laki-laki. ${ }^{10}$

Pada tabel 1 diatas Infeksi terdiri dari infeksi primer dan infeksi sekunder. Pada infeksi primer antibodi IgM muncul pada hari ke 3-5 sejak gejala dan bertahan untuk jangka waktu 30-60 hari. Antibodi IgG muncul disekitar hari ke 14 dan bertahan seumur hidup. Infeksi dengue sekunder ditunjukkan dengan tingkat antibodi IgG meningkat dalam 1-2 hari setelah gejala muncul dan merangsang respon antibodi IgM setelah 20 hari infeksi. ${ }^{11}$ Infeksi primer pada penelitian ini hanya terdapat di DBD derajat I dan II, sedangkan derajat III tidak ditemukan. Pembagian infeksi sekunder pada masingmasing derajat yaitu pada derajat II dan III. Penelitian ini sejalan dengan Irwadi (2007) bahwa distribusi infeksi primer hanya ditemukan DBD derajat I dan II.Infeksi dengue sekunder terjadi peningkatan titer antibodi IgG secara tiba-tiba sehingga infeksi dengue sekunder umumnya memberikan gejala klinis yang berat. ${ }^{2}$ 
Peningkatan hasil SGOT dan SGPT dimana peningkatan yang paling tinggi terdapat pada SGOT (Suryaatmadja, 2004) ${ }^{12}$. Pada proses infeksi dengue salah satu respon imun yang berperan adalah respon imun seluler yaitu limfosit T. Sel limfosit T, baik Thelper (CD4+) dan T-sitotoksik (CD8+), akan teraktivasi akibat stimulus sitokin seperti IFN atau karena adanya infeksi makrofag oleh virus. Sel T CD4+ mengaktivasi sel limfosit B untuk kemudian membentuk immunoglobulin (terutama $\lg \mathrm{M}$ dan $\lg \mathrm{G}$ ) yang berasal dari selsel plasma limfosit. Pembentukan immunoglobulin (khususnya IgM) di awal saat dengue masuk ke dalam tubuh berperan untuk mengeliminasi virus. Keberadaan proses ini dapat memperingan penyakit selama kadar IgM cukup banyak. Jika kadar IgM rendah, infeksi akan berjalan lebih berat karena proses eliminasi virus tidak memadai. ${ }^{12}$

Pemeriksaan antibodi dengue $\lg G / \lg M$ digunakan untuk menentukan demam yang diakibatkan virus dengue atau demam yang disebabkan oleh penyebab lain dan menentukan infeksi primer atau sekunder. ${ }^{11}$

Pada penelitian ini didapatkan bahwa IgG positif sebanyak $21(65.6 \%)$ orang dan IgG negatif sebanyak 11 (34.4\%) orang. Berdasarkan teori, pada infeksi primer IgG akan mulai meningkat pada hari kelima dan terus meningkat sampai puncaknya pada hari ke-14 sedangkan pada infeksi sekunder lgG akan meningkat dengan cepat setelah hari kedua. $^{11,12}$

Pada penelitian ini dijumpai rerata kadar SGOT dan SGPT yang tinggi, pada pengamatan yang dilakukan bahwa kadar SGOT lebih tinggi dari kadar SGPT85.3 U/L dan $65.06 \mathrm{U} / \mathrm{L}$.Penelitian ini sejalan dengan penelitian Anggraini (2012) bahwa SGOT terdapat peningkatan 1-3 kali lipat dari normal. Sedangkan ada perbedaan pada SGPT bahwa SGPT masih dalam keadaan normal. Penelitian Oleh Satriani (2010) bahwa rerata kadar SGOT dan SGPT yaitu $150.9 \mathrm{U} / \mathrm{L}$ dan $58.9 \mathrm{U} / \mathrm{L}$. Hasil penelitian ini sebanding dengan penelitian di Tan Tock Seng Hospital, Singapore terdapat 690 pasien dengue dimana 31\% terkena DBD. Peningkatan SGOT sekitar $86 \%$ dan SGPT 46\% (lee, 2012). ${ }^{11}$

Penelitian yang dilakukan oleh Santosa (2010) di RSUP Dr. Karyadi Semarang bahwa kadar serum SGOT $99,0 \%$ dan SGPT $52 \%$ lebih tinggi dari normal, dimana SGOT dan SGPT sebagai penanda kerusakan hepatosellular. ${ }^{12}$

Pada penelitian ini dijumpai peningkatan SGOT lebih tinggi dibanding SGPT, hal ini sesuai dengan hasil penelitian oleh Seneviratne dan Malavige yang melaporkan adanya peningkatan SGOT yang lebih tinggi dibanding SGPT pada penderita dengue, dengan penurunan SGOT yang lebih cepat 
dibanding SGPT dan mencapai nilai normal kembali setelah minggu ke-2. Peningkatan SGOT yang lebih besar dibandingkan SGPT karena selain dihati, SGOT juga dilepaskan oleh otot skeletal dan miokardium yang juga merupakan organ target infeksi dengue (ALF, 2009). ${ }^{7}$ Peningkatan SGPT yang terjadi lebih spesifik untuk organ hati, dapat menunjukkan adanya proses kerusakan yang terjadi pada sel hati. Peneliti lain membuktikan bahwa virus dengue dapat menginfeksi sel Kuffer manusia, tetapi bukan untuk bereplikasi, melainkan selsel ini mengalami apoptosis kemudian difagositosis. Hepatosit mungkin menjadi target primer di hati, terutama untuk DBD berat dan fatal.Pada satu penelitian lain dikatakan virus dengue dapat menginfeksi hati menyebabkan hepatitis, didapatkan peningkatan SGOT dan SGPT pada saat dirawat dan terus meningkat sampai minggu ke 2 saat sakit yang kemudian menurun sampai normal dalam 2-3 minggu kemudian. ${ }^{8}$

\section{KESIMPULAN}

Terdapat hubungan positif lemah tidak bermakna antara pemeriksaan IgGdengue dengan uji fungsi hati (SGOT dan SGPT) pada pasien demam berdarah dengue (DBD)

\section{DAFTAR PUSTAKA}

1. Soedarto (2011).Buku ajar parasitologi kedokteran. Jakarta: Sagung Seto, pp: 273-274.

2. Irwadi, Arif, hardjoeno (2007). Gambaran serologis IgM - IgG cepat dan hematologi rutin penderita $\mathrm{dbd}$. indonesian journal of clinical pathology and medical laboratory, 13 (2): 45-47.

3. Pramestuti N, Djati AP. (2013). Distribusi vektor demam berdarah dengue ( $\mathrm{dbd}$ ) daerah perkotaan dan perdesaan di kabupaten banjarnegara. Bul. Penelit. Kesehat. 41(3): 163-164.

4. Sutanto I, Ismid I, Sjarifuddin PK, Sungkar $S$ (2011). Buku ajar parasitologi kedokteran. Edisi keempat. Jakarta: FKUI, pp: 265-266.

5. Kemenkes RI (2011). Petunjuk teknis : penggunaan rapid diagnostic test (rtd) untuk penunjang diagnosis dini DBD. http://www.pppl.depkes.go.id/_asset/_ download/PETUNJUK_TEKNIS_RDT_ Dengue.pdf. Diakses Januari 2016.

6. Kemenkes RI (2013). Profil kesehatan indonesia 2012. Jakarta: Kementerian Kesehatan RI, pp 96-97.

7. ALF (2009). Newly diagnosed nonalcoholic fatty liver disease.http://www.liver foundation.org/downloads/alf_download_9 21.pdf. Diakses November 2015. 
8. Satriani L (2009). Korelasi kadar transforming growth factor-beta 1 plasma dengan sgot dan sgpt serum pada demam berdarah dengue. Semarang. Universitas Diponegoro. (Tesis).

9. Dahlan S (2010). Statistik uji kedokteran dan kesehatan.Edisi 5.Jakarta : Salemba Medika, pp 167-183.

10. Nopianto H (2012). Faktor-faktor yang berpengaruh terhadap lama rawat inap pada pasien demam berdarah dengue di rsup $\mathrm{dr}$ kariadi semarang. Semarang. Universitas Diponegoro. (Skripsi).

11. Handoko D, Epid M, Prasetyowati EB (ed) (2011). Modul pengendalian demam berdarah dengue. Jakarta: Kemenkes RI.

12. Tantra AAM (2011). Korelasi antara lademam dengan kadar IgM dan IgG anak yang menederita demam berdarah dengue. Universitas Diponegoro. (Skripsi).

13. Suryaatmadja M (2004). Tabel konversi satuan si-konvensional \& nilai

rujukan dewasa-anak parameter laboratorium klinik. Jakarta: Perhimpunan Dokter Spesialis Patologi Klinik Indonesia. 